\title{
Kestävän kehityksen kestämätön tragedia
}

\author{
Lotta Aho \& Maarit Laihonen
}

\begin{abstract}
Abstrakti
Tässä artikkelissa tarkastelemme talouskasvun ja kestävän kehityksen periaatteiden ristiriitaisen suhteen muodostumista käsitteellisellä tasolla. Tarkastelemme erityisesti sitä, miten periaatteiden konkreettinen yhteensovittamattomuus päätöksentekoa ja toimintaa ohjaavassa uusliberaalissa kansainvälisessä järjestyksessä tekee kestävään kehitykseen määritelmällisesti kuuluvan sukupolvien välisen tasa-arvon mahdottomaksi. Aloitamme tarkastelun kestävän kehityksen politiikan synnystä 1950-luvun puolivälistä alkaen ja sitä seuranneista kansainvälisistä politiikkatoimista, jotka ovat eri aikoina tähdänneet kestävän kehityksen tavoitteeseen eri keinoin. Tuomme esiin, että kansallinen itsemääräämisoikeus ja vapaaehtoisuus ovat sälyneet keskeisinä johdattavina ajatuksina näiden politiikkatoimien muotoutumisessa. Esitämme, että aidosti ympäristöllisesti kestäville politiikkavalinnoille ei ole nykyisessä järjestyksessä esimerkiksi tieteellisiä, talousrationaliteettiin tai lainsäädännön rakenteisiin perustuvia esteitä, vaan esteet ammentavat ideologisesta uskosta talouden ensisijaisuuteen yhteiskunnallisesti merkittävissä päätöksissä.
\end{abstract}

\section{Johdanto}

Teollinen vallankumous mahdollisti kulutuksen kasvun ja loi edellytykset kapitalistiseen yhteiskuntamalliin pohjautuvalle, jatkuvasti kasvavan kulutuksen talousjärjestelmälle, joka on johtanut ympäristön tilan heikentymiseen resurssien ylikulutuksen ja saastumisen sekä muiden laajamittaisten ympäristötuhojen kautta. Ilmastonmuutos on jo pitkälti peruuttamaton, eivätkä Pariisin vuoden 2015 ilmastokokouksen sinänsä kattavat, mutta auttamattoman riittämättömät päästövähennyslupaukset näytä tilannetta parantavan. Esimerkiksi kuluneena vuonna 22.8.2015 maapallon vuodessa tuottamat uusiutuvat luonnonvarat oli kulutettu loppuun vuoden 2015 
osalta. Ihmiskunta elää jatkuvasti "yli varojensa" ekologisessa mielessä.

Tätä kehitystä on perusteltu muun muassa uusklassisen taloustieteen opilla, jonka mukaan talouskasvun lisääminen lisää määritelmällisesti hyvinvointia (Goodland ja Ledec 1987; Jackson 2011; ks. myös WCED 1987). Kuitenkin jo 1970-luvulla Rooman klubin julkaisema raportti varoitti kasvun rajoista teollisen tuotannon kasvun seurauksena. 1980-luvulla uusliberalistisen politiikan lopullisen voittokulun myötä myös kestävä kehitys päädyttiin määrittelemään tapahtuvaksi talouden ehdoilla. Vallitseva uusliberaali poliittinen paradigma tunnustaa ympäristöongelmien olemassaolon, mutta nämä ajatellaan ratkaistavan teknologisella kehityksellä. Teknologinen kehitys mahdollistaa luonnonvarojen yhä kasvavan kulutuksen, jota puolestaan tarvitaan hyvinvointia näennäisesti lisäävään talouskasvuun. Ympäristöllisen kestävyyden määritteleminen talouskasvulle alisteiseksi tekee siitä käytännössä merkityksettömän käsitteen, koska kestämättömyyteen johtaneita syitä ei tällöin kyseenalaisteta. Myös teollisuudelle ja yrityksille kestävyydestä on muotoutunut usein lähinnä instrumentaalista arvoa omaava termi, kuten yhteiskuntavastuusta. Kestävyys- ja vastuuraportoinnilla sekä yleisemmin näiden termien esillä pitämisellä haetaan strategisesti tärkeää legitimiteettiä toiminnalle ilman aitoja vaateita tai pyrkimyksiä kestämättömyyden ydinongelmien ratkaisuun (esim. Blowfield 2007; Frankental 2001; Vogel 2005).

Kestävä kehitys on tähän sakkka määritelty ihmiskeskeisestä tai jopa talouskeskeisestä näkökulmasta. Toisin sanoen talouteen liittyvät odotukset (mm. kulutuksen ja tuotannon kasvu, suopeat olosuhteet yritystoiminnalle) ovat olleet päätöksenteossa ensisijaisia ekologiseen kestävyyteen verrattuna. Tässä artikkelissa esitämme, että vallitsevassa uusliberaalissa kansainvälisessä talousjärjestyksessä "talouden hyvinvoinnista" on huolehdittu konkreettisin poliittisin toimin, kun taas ympäristökysymykset jäävät suhteessa usein vapaaehtoisen toiminnan varaan. Kansainvälisellä uusliberalistisella järjestyksellä viittaamme globaalin taloudellisen hallinnan järjestämistapaan, jossa talouden edellytykset on turvattu vapauden nimissä, mutta kestävän resurssien käytön oletetaan toteutuvan saman vapauden viitekehyksessä. Ekologinen taloustiede pitää pahenevia ympäristöongelmia poliittisten, taloudellisten ja sosiaalisten valta-asemien ja -rakenteiden tuotteena. Näiden rakenteiden kriittinen tarkastelu ekologisen kestävyyden näkökulmasta vaatii niihin sisältyvien ympäristöhallintomallien ekologisten vaikutusten 
analysointia (Newell 2008). Voiko tällainen talous, joka perustuu jatkuvalle kasvulle ja luonnonvarojen kulutukselle, olla koskaan kestävä? Onko todellista kestävyyttä mahdollista saavuttaa, mikäli taloudelle ja kulutukselle ei aseteta pakottavia rajoja, joissa lähtökohtana on ympäristökeskeinen luonnonvarojen uusiutuminen?

Tässä artikkelissa luomme katsauksen luonnonvarojen käyttöön perustuvan talouskasvun ja kestävän kehityksen liiton muodostumiseen. Tuomme esiin, miten tämä liitto tekee kestävään kehitykseen määritelmällisesti kuuluvan sukupolvien välisen tasa-arvon mahdottomaksi resurssien käytön jatkuvasti lisääntyessä ja ylittäessä kestävät rajat luonnonvarojen rajallisessa maailmassa. Väitämme, että uusliberaalin politiikan institutionalisointi kansainväliseen ympäristöpolitiikkaan on tehnyt lähes mahdottomaksi esittää tai saada hyväksytyksi kansallisiin ja kansainvälisiin instituutioihin implementoiduille poliittisille agendoille aidosti vaihtoehtoisia lähestymistapoja, joilla ekologinen kestävyys voitaisiin turvata institutionaalisesti. Nostamme esimerkiksi yhtiöoikeuden ja uusliberalistiseen paradigmaan kuuluvan oikeustaloustieteen leviämisen lainsäädännön taustalle. Esimerkin avulla voidaan tarkastella, miten uusliberalismi on porautunut instituutioihin, normeihin ja ihmisten ajatteluun niin syvälle, että uusliberalismin periaatteet muodostuvat itsestäänselvyyksiksi ja välttämättömyyksiksi. Samalla kuitenkin osoitamme, ettei esimerkiksi mannereurooppalaisessa ja erityisesti Suomen lainsäädännössä ole varsinaisia laillisia esteitä ekologisesti kestävän liiketoiminnan harjoittamiselle.

Lopuksi pohdimme viime vuosikymmeninä esiteltyjen vaihtoehtoisten talousjärjestelmämallien avulla, miten ja millä keinoin nykytilaan voitaisiin saada muutos ja miten talouden rakenteita voitaisiin muotoilla kestävämmälle perustalle. Kritisoimme vallitsevaa hegemoniaa ekologisen taloustieteen viitekehyksessä. Tässä viitekehyksessä talous ajatellaan osaksi ekosysteemiä, eikä siitä erillisenä osana, joka on ensisijainen ekosysteemin nähden.

\section{Talouskasvun ja kestävän kehityksen liiton muodostuminen}

Kansainvälisen ympäristöliikkeen synty ajoitetaan useimmiten 1960-1970 -lukujen taitteeseen. Myös kansainvälinen ympäristöhallinto otti samaan aikaan ensi askeliaan uuden hallintomuodon rakentamisessa (Pattberg ja 
Widerberg 2015). Näiden taustalla olivat havainnot luonnonvarojen käytön kasvusta enenevässä määrin ja sen seikan tunnustaminen, että ihmiskunta oli jo aiheuttanut tuhoa ympäristölle globaalissa mittakaavassa (Kates, Turner ja Clark 1993). Näitä koskevat tieteelliset havainnot vauhdittivat YK:n ensimmäisen ympäristökonferenssin järjestämistä 1972. Samana vuonna julkaistiin myös Rooman klubin kattava raportti Kasvun rajat, joka nosti ympäristöasioiden merkitystä kansainvälisen politiikan agendalla tuomalla esille luonnonvarojen ehtymisen sekä muita resurssien ylikäyttöön ja tuotannon kasvuun liittyviä ympäristöongelmia, kuten saastumisen.

Kattavan kansainvälisen ympäristöhallintojärjestelmän perustamisessa haluttiin ottaa huomioon kehitysmaat ja niiden intressit päästä osalliseksi talouskasvusta (Bernstein 2001). Tukholman ympäristöjulistuksen (Declaration of the United Nations on Human Environment 1972) ja myöhemmin koko kestävän kehityksen järjestelmän ohjaavaksi periaatteeksi tuli näin ollen kansallisen itsemääräämisoikeuden periaate, vaikka lukuisia suuntaa-antavia ja eri tasoja käsitteleviä toimintamalleja oli tuolloin jo esitelty lukuisissa kansainvälisissä foorumeissa. Periaate tarkoittaa, että ympäristötavoitteiden asettaminen on yksinomaan kansallisvaltioiden päätäntävallassa. Käytännössä tämä tarkoitti, että kansallisvaltiot voivat suvereniteettiperiaatteeseen vedoten aina asettaa talouskasvun ympäristöasioiden edelle esimerkiksi jättämällä ratifioimatta kansainvälisiä ympäristösopimuksia taloudellisiin intresseihinsä vedoten.

Taloudellisen yhteistyön ja kehityksen järjestö OECD:n vuonna 1984 järjestämä Ympäristö- ja talouskonferenssi esitti tavoitteen lisätä taloudellisten ohjauskeinojen käyttöä ympäristöpolitiikassa (Colby 1991). Tämän lisäksi konferenssissa korostettiin ympäristönsuojelun ja talouskasvun positiivista yhteyttä. OECD-maita ja niiden instituutioita alettiin ohjata ajattelemaan talouskasvua ja ympäristönsuojelua erottamattomina ilmiöinä (Bernstein 2001). Useat tutkijat (mm. Bernstein 2001; Newell 2008; Pattberg ja Wideberg 2015) pitävät 1980-luvun alkua aikana, jolloin uusliberaali poliittinen paradigma alkoi yleisemmin dominoida kansainvälistä ympäristöpolitiikkaa. Uusliberaalin ympäristöpolitiikan tunnusmerkkeinä voidaan pitää uskoa markkinamekanismien (esimerkiksi päästökauppa) ja teknologisen kehityksen mahdollisuuksiin ratkaista kestämättömästä kulutuksesta johtuvat ongelmat (Bernstein ym. 2010; Mitchell 2008), talouden asettamista etusijalle ympäristöön nähden ja status quon suosimista (Pattberg 
ja Widerberg 2015), lyhyen aikavälin voittojen priorisointia pitkän aikavälin kestävyyden kustannuksella (Spash ja Ryan 2012) sekä talouden jatkuvan laajenemisen pitämistä sine qua non -ehtona onnelliselle, kukoistavalle yhteiskunnalle (Peck 2010).

Näiden kirjoittajien mukaan myös kestävän kehityksen määritelmä, joka tehtiin Yhdistyneiden kansakuntien Ympäristön ja kehityksen maailmankomission raportissa (WCED 1987), palvelee lähinnä ylikansallisten taloudellisten toimijoiden etuja. Koska kyseinen määritelmä on sopusoinnussa vapaan kaupan, talouskasvun ja markkinavoimien lisäämisen kanssa sekä peräänkuuluttaa talouden ja ympäristöasioiden vahvempaa integraatiota, oikeuttaa se samalla edellä kuvailtua uusliberalistista ympäristöhallintomallia. Uusliberaalissa ajattelussa esimerkiksi yksityinen voitontavoittelu asettuu vapauden muotona keskeiseksi arvoksi (Mont Pelerin Society 1947). Uusliberaalissa hallintamallissa tätä periaatetta tulee kunnioittaa esimerkiksi sitovien ympäristösäännösten kustannuksella. Tällainen periaatteiden priorisointi käytännössä nostaa talousajattelun kestävyyden periaatteiden yläpuolelle (ks. Mitchell 2008; Newell 2008). Vaikka Brundtlandin työryhmän raportti toi kestävyyden käsitteen valtavirtapolitiikkaan, se ei yrittänyt muuttaa maailman talousjärjestystä, vaan piti talouskasvua johtavana normina, johon kansainvälisen ympäristöhallinnon tulisi sopeutua (Bernstein 2001).

Daly (1990) on huomauttanut, että WCED:n raportissa käytetään käsitteitä ristiriitaisesti. Taloudellinen kasvu on määrällistä, kun taas kehitys laadullista. Kasvu ilman kehitystä on siis mahdollista, kuten myös kehitys ilman kasvua. Tämän vuoksi raportissa kestävän kehityksen kannalta keskeisenä pidetty 5-10 prosentin vuotuinen talouskasvu on vähintäänkin kyseenalainen (ks. myös Colby 1991). Myös sisäisesti ristiriitainen termi "kestävä kasvu" on saanut merkittävää jalansijaa uusliberaalissa ympäristöhallinnossa (Bernstein 2001; Daly 1993). Tätä termiä käyttävät niin Euroopan unioni, OECD, Maailmanpankki, Kansainvälinen energiajärjestö IEA kuin myös tutkijat (esimerkiksi Journal of Environmental Economics and Management -lehdessä).

Rion ympäristö- ja kehityskokouksessa 1992 (Earth Summit) uusliberalistinen lähestymistapa kestävään kehitykseen vahvistettiin kansainvälisiin ympäristöhallintarakenteisiin erityisesti vapaaehtoisuuden kattavan periaatteen muodossa. Myös muun muassa markkinamekanismien käyttö 
ilmastopolitiikan välineenä kirjattiin ilmastosopimukseen (Böhm, Misoczky ja Moog 2012). Kokouksen aikoihin oli jo yleisesti hyväksytty näkemys, että kaupan ja rahoituksen vapauttaminen on edellytys ympäristöongelmien ratkaisulle (Bernstein 2001). Kokous jatkoi siis osaltaan OECD:n ja WCED:n luomaa ympäristön ja talouden "epäpyhää liittoa" ja vahvisti näkemystä, että ympäristöongelmat pitää ratkoa talouden ehdoilla.

Ratkaisujen siirtäminen edellä kuvattuihin vapaaehtoiseen toimintaan ja markkinamekanismeihin aiheuttaa poliittisia ongelmia kahdella keskeisellä tavalla. Ensinnäkin demokraattisista elimistä irrotetut päätöksentekojärjestelmät kärsivät ulkoisen oikeutuksen puutteesta ja eriarvoistavista toimintamalleista edustuksellisuuden suhteen (Johansson 2012). Tämä johtaa paitsi päätöksenteon elitismiin myös siihen, ettei taloudellisten toimijoiden osallistumiselle järjestelmien kehittämiseen ja konkreettiseen toimintaan ole takeita. Jää epäselväksi, ovatko taloudelliset toimijat sitoutuneita esimerkiksi jakamaan tarpeellista tietoa ja osaamista tai muuttamaan perustavanlaatuisia arvotuksiaan toimintamallien muutosten mahdollistamiseksi (esim. Bled 2009; Kolk ym. 2008). Demokraattisissa viitekehyksissä toimiva ympäristöhallinto ei tietenkään aina takaa kestävyyttä (ks. Levy 2011). Toisaalta kansainvälisen ympäristöhallinnon asettaminen perinteisten pakottavien hallintomallien ulkopuolelle ei ole johtanut merkittäviin parannuksiin kestävyyden edistämisen kannalta, mikä tekee vapaaehtoisuuteen perustuvien mallien toimivuudesta kyseenalaista (Paavola ym. 2009). Toiseksi vapaaehtoisuuteen ja markkinoihin perustavien järjestelmien toimivuus on kyseenalaista tai vähintäänkin auttamattoman hidasta siihen nähden, mikä kansainvälisen tutkijayhteisön jakama käsitys muutoksen tarpeen kriittisyydestä globaaleiden ympäristöongelmien suhteen on (Borck ja Coglianese 2009; ks. myös Banerjee 2012).

Seuraavaksi paneudumme tarkemmin juuri taloudellisen toiminnan ja toimijoiden rooliin kestävän kehityksen globaalissa tavoittelussa aiemman tutkimuksen valossa keskittyen yritystoimintaan. Keskustelua on käyty viime aikoina erityisesti kriittisen yritysvastuun tutkimuksen alueella, jossa yritysten poliittisen roolin on havaittu olevan sidoksissa taloudelliseen toimintaan liittyviin ideologisiin taustoihin (esim. Djelic ja Etchanchu 2015; Sandoval 2015). Laajempaan poliittiseen ja demokraattiseen kehykseen liittyviä ongelmia taloudellisen toiminnan hallinnan suhteen on 
analysoitu erityisesti sen osalta, millaisiin hegemonisiin intresseihin ristiriitojen taustat liittyvät (Banerjee 2008).

\section{Ympäristöllisesti kestävä liiketoiminta ja vapaaehtoisuuden paradoksi}

Kestävän kehityksen diskurssi laajeni nopeasti koskemaan yrityksiä ja niiden osallistumista "kestävyystalkoisiin". Rion 1992 neuvotteluista lähtien, mutta osittain jo ennen sitä 1980-luvulta alkaen, yritykset tuotiin mukaan keskeisiksi kestävyyttä edistäviksi toimijoiksi poliittisen ja kansalaispaineen myötä. Käytännössä paineesta seurasi vaatimus siitä, että yritykset ryhtyisivät kehittämään toimintaansa ekologisesti kestävämmäksi pakottavan lainsäädännön ulkopuolella esimerkiksi resurssitehokkuuden ja päästöjen hillitsemisen suhteen.

Useissa maailmankolkissa pakottava sääntely tai sen valvonta ja siihen liittyvät pakkokeinot itsessään ovat vähäisiä. Vapaaehtoinen toiminta näyttää usein jäävän varsinkin vauraissa maissa päämajaansa pitävien yritysten harrastetoiminnaksi. Aiemman tutkimuksen valossa tällä saattaa olla taloudellisia ja mainehyötyjä yritykselle, mutta konkreettiset sosiaaliset ja ympäristöhyödyt ovat jääneet epäselviksi (esim. Blowfield 2007; Dyllick ja Muff 2015). Tämä yritysten toiminta kulkee useilla nimikkeillä. Se esiintyy myös monenlaisissa yritys-, ala- tai maakohtaisissa normeissa. Vapaaehtoisista järjestelmistä mainittakoon ympäristösertifikaatit (esim. yleiset ISO-standardit ja alakohtaiset järjestelmät) sekä näihin liittyvät vastuullisuusraportointijärjestelmät. (Ks. esim. Carroll 1999; Dahlsrud 2008.) Yritysvastuun käsitteellinen viidakko on omaa käsittelyä vaativa lukunsa, joten keskitymme tässä vapaaehtoisen toiminnan vaikutuksiin vain ympäristön hyvinvoinnin kannalta.

Ympäristön hyvinvoinnin parantumista yritysten vapaaehtoisten toimien johdosta ei ole yksiselitteisesti pystytty osoittamaan (Dyllick ja Muff, 2015). Vastuuta on ennemmin pyritty ulkoistamaan yksittäisten kulutusvalintojen vastuullisuuden peräänkuuluttamisen kautta eri toimijoiden (hallinto, järjestöt, yritykset) tahoilta, ikään kuin tuotannolla ja tuotantotavoilla ei olisi merkitystä mikäli ihmiset vain ostavat tuotteita. Esimerkkejä tästä ovat vaikkapa lentoyhtiöiden tarjoamat vapaaehtoiset hiilidioksidipäästöjen 
kompensointimaksut, kestävän kuluttamisen ohjelmat ja oppaat tai tuotteisiin lisätyt ympäristömerkit ja -sertifikaatit. Vapaaehtoisen toiminnan vaikutusten ja tehokkuuden epävarmuudesta huolimatta ympäristövastuu on vahvassa suosiossa niin organisaatioiden juhlapuheissa kuin kansainvälisillä areenoilla.

Esimerkiksi suomalaisten suuryritysten internet-sivuilla yleensä heti ensimmäisistä valikoista löytyy näkyvästi tietoa yrityksen suhteesta kestävään kehitykseen: käytetyt järjestelmät, vastuun integroiminen strategiaan, sen osa yritysten visiossa ja niin edelleen. Nämä ovat myös asioita, joita yritysten odotetaankin esittelevän keskeisenä osana toimintaansa ja joita usein pidetään suorana osoituksena yrityksen vastuullisuudesta (Montiel ja Delgado-Ceballos 2014). Yritysten tiedotustoiminnassa tai edes tutkimuksessa harvemmin kuitenkin paneudutaan vastuullisuusviestinnän taustalla olevaan todellisuuteen (esim. Salzmann, Ionescu-Somers ja Steger 2005). Osittain tämä ongelma johtuu siitä, että sosiaalisten ja ympäristövaikutusten mittaaminen on huomattavasti vaikeampaa kuin taloudellisten. Perustavanlaatuisemmat kysymykset myös pysyvät helposti poissa julkisesta keskustelusta ja jäävät tutkijoiden ja kriittisten ryhmien sisäiseksi pohdinnaksi, ellei esimerkiksi yksittäinen yritysskandaali nosta näitä ongelmia pinnalle, kuten tuore Volkswagenin päästömittausskandaali osoittaa. Väitämmekin, että usko siihen, että negatiiviset ulkoisvaikutukset hoituvat vapaaehtoisin toimin, elää vahvana markkinauskoisessa liiketoimintaympäristössä.

Vapaaehtoisuus politiikkatoimena sisältää merkittäviä ongelmia. Pakottavan sääntelyn vipuvartena toimii sääntelyn rikkomuksista seuraavat seuraamukset ja toimintaa valvoo ulkopuolinen taho, jolloin tutkinta ja sanktioiden langettaminen tapahtuvat puolueettoman tahon toimesta demokraattisesti säädetyn prosessin puitteissa. Vapaaehtoisten parantamistoimien vipuvartena sen sijaan toimii ainoastaan mahdollinen julkinen tai sidosryhmäpaine ja toimintaa "valvovat" suoranaisesti vain toimijat itse. Yritysvastuun sydämessä vaalittu niin sanottu win-win-ajattelu - yritykset saavat maine-etuja ja sidosryhmille taataan liiketoiminnan negatiivisten ulkoisvaikutusten väheneminen - on saanut laajalti kritiikkiä osakseen, kun konkreettiset toimet näyttävät toistuvasti jäävän puheen tasolle (esim. Banerjee 2014; Barkemeyer ym. 2011). Yritysvastuun rakenteellinen kritiikki, vastuun perustana oleva markkinausko ja laajemmat järjestelmäkysymykset ovat alkaneet saada sijaa tieteellisissä keskusteluissa erityisesti 
viimeisen kymmenen vuoden aikana (Midttun 2005; Midttun ym. 2006; ks. myös Huehn 2008).

Uusliberaali kansainvälinen hallintatapa perustuu sääntelyn purkamiselle, vapauden ideaalille ja näiden tukemiselle suorin poliittisin toimin, jotka antavat liiketoiminnalle mahdollisuuden menestyä sen aiheuttamista ulkoisvaikutuksista huolimatta (Cato 2009). Esimerkiksi päästökauppa antaa saastuttamisoikeuden pienelle joukolle, käytännössä yrityksen osakkeenomistajille, vaikka ulkoisvaikutukset koskevat kaikkia. Yritystoiminnan kasvun logiikkaan pureutuminen on tässä mielessä välttämätöntä kansainvälisen talousjärjestelmän ympäristöongelmien ymmärtämiseksi. Ongelman keskiöön nousevat paitsi kansainväliseen yritystoiminnan ja vapaaehtoisten toimien sääntelyyn liittyvät kysymykset myös kansallinen yrityslainsäädäntö. Nämä yhdessä määrittelevät, millaisen roolin yritykset saavat yhteiskunnassa laajemmin.

\section{Lainsäädäntö, kansainväliset normit ja kestävä liiketoiminta}

Anglosaksisen ja mannereurooppalaisen yhtiöoikeuskulttuurin perustavanlaatuisena erona on pidetty, että ensin mainitussa on keskitytty osakkeenomistajan voiton (shareholder value) maksimoimiseen, kun taas jälkimmäisessä on tavoiteltu laajemman sidosryhmän kokonaishyvinvoinnin maksimointia (Hertig 2000). Tämä ero on viime vuosikymmeninä hälventynyt, sillä mannereurooppalainen kulttuuri on saanut väistyä anglosaksisen tieltä. Myös omistajavallan käytössä on perinteisesti ollut eroja. Institutionaaliset sijoittajat ovat olleet pitkälti "hiljaisia sijoittajia” Manner-Euroopassa (Horn 2012). Rahoitusmarkkinoiden globalisaation ja tuotto-odotusten kasvun myötä niin amerikkalaiset kuin eurooppalaiset institutionaaliset sijoittajat ovat alkaneet käyttää ääntään aktiivisesti yhtiön hallinnossa (Hertig 2000).

Edellä kuvatut kehityskulut kuvaavat konkreettisesti uusliberaalin poliittisen paradigman leviämistä Eurooppaan. Näiden kehityskulkujen johdosta akateeminen, liike-elämän ja hallinnollinen eliitti on Hansmannin ja Kraakmannin (2000) mukaan myös saavuttanut konsensuksen osakkeenomistajamallin paremmuudesta ja siitä, että yhtiö on vastuussa ainoastaan osakkeenomistajille, ja että nämä ovat ainoita, joiden tulee osallistua yhtiön hallintoon. Tämä heijastaa Peckin (2010) huomiota siitä, että 
uusliberalismista on tullut sisäistetty ja normalisoitunut ajattelutapa sen sijaan, että se ymmärrettäisiin ideologiana, joka sisältää jo lähtökohtaisesti tiettyjä arvovalintoja, jotka ohjaavat päätöksentekoa. Yritysoikeudessa yksi tällainen ajattelutavan ilmentymä on taloustieteen Chicagon koulukunnasta alkunsa saaneen oikeustaloustieteen vahvistuminen oikeustieteilijöiden ja lainsäätäjien keskuudessa. Grembi (2007) kutsuu tätä ilmiötä oikeusjärjestyksien kolonisaatioksi. Chicagon koulukunnan perusoletuksiin kuuluu omistajan halu maksimoida sijoituksensa arvo. Tulevien sukupolvien intressit eivät mahdu opin piiriin, vaan omistajan oletetaan aina diskonttaavan yhtiön sijoitukset tuleviin toimiin. Ainoa tämän koulukunnan tunnustama ympäristöllinen arvo on se, minkä markkinat hyödykkeiksi muutetuille ympäristöarvoille kullakin hetkellä antavat. (Lewin 1995). Oikeustaloustiede ei siis toisin sanoen tunnusta yhtiöiden suoraa velvollisuutta osallistua kestävän kehityksen toteuttamiseen.

Toisaalta on huomattava, ettei osakkeenomistajan aseman vahvistuminen ja korostuminen tarkoita, että eurooppalaisessa kontekstissa yhtiön toiminnan ainoa tarkoitus olisi voiton tuottaminen osakkeenomistajille (Andersen ja Södersen 2011). Ison-Britannian lainsäädännössä, joka on lähimpänä Yhdysvaltain mallia, säädetään yhtiön johdon velvollisuudesta tähdätä voitontuottamiseen, mutta samalla on huolehdittava toiminnan vaikutuksesta esimerkiksi ympäristöön (UK Companies Act, section 172).

Suomessa osakkeenomistajan aseman korostaminen on johtanut siihen, että osakeyhtiön velvollisuutta tuottaa omistajilleen voittoa pidetään nykyään itsestäänselvyytenä. Säädös on kuitenkin nykyisessä muodossaan tullut osakeyhtiölakiin vasta vuonna 2006 tehdyn kokonaisuudistuksen yhteydessä. Vuoden 1978 osakeyhtiölain 12 luvun 1.2S kuului: ”Jos yhtiön toiminnalla on kokonaan tai osaksi muu tarkoitus kuin voiton tuottaminen osakkeenomistajille, yhtiöjärjestykseen on otettava määräys voiton käytöstä”. Voiton tuottaminen osakkeenomistajille on ollut implisiittisesti osakeyhtiön toiminnan tarkoituksena, mutta tarkoitus on voinut myös olla kokonaan tai osaksi toinen. Voiton tuottamisen eksplisiittinen ensisijaisuus on siis vasta vuodelta 2006, jolloin pykälän loppuosa kuuluu: "ellei yhtiöjärjestyksessä toisin määrätä”. Hallituksen esityksestä (HE 109/2005) yhtiön toiminnan vaihtoehtoinen tarkoitus ei kuitenkaan käy ilmi, koska muutosta vähätellään lausumalla muun muassa, että "[y]htiön toiminnan tarkoitus on ehdotuksen mukaan edelleen voiton tuottaminen osakkeenomistajille", ja 
että “[s]äännös vastaa pääasiallisen sisältönsä osalta voimassa olevan lain 12 luvun 1 S:n 2 momenttia”.

Säännöksen muuttaminen implisiittisestä olettamasta toiminnan päätarkoituksesta lähes imperatiiviseksi voiton tuottamiseksi olisi kuitenkin vaatinut laajemmat perustelut. Voiton tuottamisen tarkoitus on sijoitettu lain ensimmäiseen lukuun, jossa korostetaan keskeisiä oikeusperiaatteita ja suojeltavia oikeushyviä (HE 109/2005). Suojeltaviksi oikeushyviksi muodostuvat osakkeenomistajan rajoitettu vastuu, pääoma ja yhdenvertaisuus. Toisaalta ensimmäisen luvun viimeinen pykälä korostaa tahdonvaltaisuutta, eli osakkeenomistajien oikeutta määrätä yhtiön toiminnasta. Näin ollen Suomessa lainsäädäntö edelleen mahdollistaa osakeyhtiön toiminnan tarkoituksen määrittelyn myös muuksi kuin voiton tuottamiseksi osakkeenomistajille. Osakeyhtiö voidaan siis perustaa myös harjoittamaan ekologisesti kestävää liiketoimintaa. Yksityinen osakeyhtiö voidaan myös osakkeenomistajien enemmistön päätöksellä muuttaa ekologisesti kestävää toimintaa harjoittavaksi. Julkisenkaan osakeyhtiön toimintatarkoituksen muuttaminen ei liene mahdotonta, mikäli noudatetaan avoimuutta päätöksenteossa ja sijoittajaviestinnässä.

Esimerkkinä muusta kuin voitontavoitteluun perustuvista yrityksistä ovat niin kutsutut yhteiskunnalliset yritykset. Näiden toiminnan keskiössä on paitsi riittävä taloudellinen tuotto toiminnan ylläpitämiseksi myös se, että yrityksen toiminta pyrkii suoraan tuottamaan jotain yhteistä hyvää tai perustuu eettisille arvovalinnoille. Tässäkin tapauksessa on hallituksen esityksen mukaan kuitenkin pyrittävä tuottamaan mahdollisimman suuri taloudellinen ylijäämä. Toisaalta tahdonvaltaisuuspykälä osoittaa siihen suuntaan, että osakkaat viime kädessä päättävät asiasta. Sama koskee myös muiden Pohjoismaiden yhtiölainsäädäntöä. Yhtiökokous eli osakkaat voivat päättää toiminnalle muunkin tarkoituksen kuin voiton tuottamisen osakkaille (Andersen ja Sörensen 2011).

Vaikka eurooppalaiset osakeyhtiölait eivät määritä voiton tuottamista yhtiön ainoaksi mahdolliseksi tavoitteeksi, edellä kuvatut muutokset korostavat aiempaa enemmän voiton tuottamista ja osakkeenomistajan aseman ensisijaisuutta. Nämä myös kuvaavat kansainvälistä trendiä asettaa valtiollinen oikeusjärjestelmä palvelemaan ensisijaisesti taloutta ja talouskasvua ekologisen kestävyyden kustannuksella. Toisaalta on huomattava, ettei osakkeenomistajilla ole - ainakaan Euroopassa - laillisia esteitä kestävää 
kehitystä edistävän yrityksen perustamiseen tai muotoiluun. Toisin sanoen se, valjastetaanko yritykset ajamaan kestävää kehitystä, on kiinni paitsi valtioiden myös osakkeenomistajien tahdosta. Kuten edellä olemme osoittaneet, ei tähän kuitenkaan ole löytynyt tahtoa, eikä yrityksillä ole tämän edistämiseen kannustimia tai ideologisista syistä välttämättä edes tahtoa.

Myös ylikansallisten instituutioiden kykyä edistää kestävää liiketoimintaa suoraan tai välillisesti on pidetty heikkona. Vaikka esimerkiksi EU:lla on laaja lainsäädäntövalta yhtiöoikeuden alueella, ylikansallisia yrityksiä koskevaa sääntelyä ei ole tehty velvoittavalla tavalla. Yhtiöoikeuden alalla on käytetty Neuvoston päätelmiä, päätöslauseita ja lauselmia, jotka eivät ole jäsenvaltioita velvoittavaa lainsäädäntöä, joskin multilateraalisen luonteensa hieman vahvempia kuin unilateraaliset julistukset (Baade 1980). Näiden Neuvoston asiakirjojen tarkoituksena on olla vain poliittisia sitoumuksia tai kannanottoja, eikä EU:n perussopimuksissa ole määräyksiä niistä.

Kansainvälisen työjärjestö ILO:n ja OECD:n ylikansallisia yhtiöitä koskeva sääntely on jätetty toimintaohjeiden (code of conduct) tasolle, joissa erikseen mainitaan, ettei sääntely ole juridisesti toimeenpantavissa. YK:n laatima yritysten toimintaohjekin jättää sääntelyn tällaisten juridisesti velvoittamattomien toimintaohjeiden tasolle. Oikeustieteen puolella on kuitenkin spekuloitu, voisivatko yritysten toimintaohjeet muodostaa sellaisen kansainvälisen tapaoikeuden käytännön, että niitä alettaisiin pitää velvoittavina (Baade 1980). Tätä vastaan kuitenkin puhuu se että toimintaohjeissa eksplisiittisesti mainitaan niiden olevan ei-velvoittavia, eivätkä valtiot tai yksityiset oikeussubjektit (yritykset) siten ole niiden noudattamiseen sitoutuneita. Myös eräät ylikansallisten yhtiöiden kotimaat, Yhdysvallat etunenässä, ovat vastustaneet toimintaohjeiden muodostumista kansainväliseksi tapaoikeudeksi. Clapp ja Dauvergne (2011) esittävätkin kansainvälisten järjestöjen olevan useissa tapauksissa uusliberalistisen järjestyksen legitimiteetin ylläpitäjiä.

Kansainvälisten järjestöjen (YK, ILO, OECD) toimintaohjeet ovat kuitenkin kansainvälisiä politiikkajulistuksia, jolloin niin sanottu estoppel-sääntö tekee näiden toimintaohjeiden substanssin sisällyttämisen kansalliseen lainsäädäntöön hyväksyttäväksi. Tätä mahdollisuutta on tosin käytetty varsin säästeliäästi. Yksi syy saattaa olla tutkijoiden ja ehkä myös lainsäätäjän keskittyminen mahdollisiin ristiriitoihin Maailman kauppajärjestön WTO:n säännösten kanssa sen sijaan, että keskityttäisiin siihen, 
miten ympäristökysymyksiä voisi säännellä (Kulovesi 2014). Osaltaan myös pelko siitä, miten yritykset tiukentuneeseen lainsäädäntöön reagoivat ennaltaehkäisee ympäristönormien säätämistä (Clapp ja Dauvergne 2011). Newell (2008) on esittänyt, että valtiot, järjestöt ja pääoma jopa tekevät yhteistyötä suojellakseen sellaisten toimijoiden hegemoniaa, joiden etuja kansainväliset ympäristönormit saattaisivat uhata. Toisaalta useat yritysvastuututkijat (Moon, Crane ja Matten 2005; Scherer ja Palazzo 2008; 2011) näyttävät kannattavan vapaaehtoisia toimintaohjeita yritysten ohjenuorana ja ideaalimallina ongelmallisten asioiden käsittelyyn.

On sellaisenaan kiinnostavaa, miksi ympäristösääntely on pidetty vapaaehtoisena, kun esimerkiksi vapaakauppakysymyksistä kyetään sääntelemään kansainvälisesti velvoittavasti. Tällä hetkellä yrityksillä on eri vapaakauppasopimusten nojalla mahdollisuus haastaa valtio oikeuteen liian tiukasta ympäristösääntelystä, mutta valtiolla ei ole vastaavaa oikeutta ylikansallisia yrityksiä vastaan sitovan kansainvälisen ympäristölainsäädännön puuttuessa.

\section{Vaihtoehtoisia lähestymistapoja}

Talouden ensisijaisuuden ehdottomuuden kritiikki ja vaihtoehtoisten ympäristöhallintamallien esittäminen ei ole uusi idea. Se sai syntynsä, kun kasvavan talouden ja sitä myötä teollisuustuotannon lisääntymisen ympäristöhaitat alkoivat tulla laajaan tietoisuuteen. Tämä tapahtui esimerkiksi 1960-luvulla Murray Bookchinin pseudonyymillä Lewis Herber kirjoittaman Our synthetic environment-teoksen tai kuuluisamman Rachel Carsonin Hiljainen kevät -teoksen myötä. Suurempaa näkyvyyttä idea alkoi saada kuitenkin vasta 1980-1990-lukujen taitteessa, jolloin kansainvälisiä instituutioita alettiin rakentaa kestävän kehityksen ympärille (esim. Lélé 1991). Myös taloustieteen sisälle oli syntynyt erilaisista paradigmoista ammentavia koulukuntia, tärkeimpinä ympäristötaloustiede (environmental economics) ja radikaalimpi ekologinen taloustiede (ecological economics), jo 1960-luvulta alkaen. Näistä jälkimmäinen nostaa eksplisiittisesti ympäristön talouden yläpuolelle ja tarkastelee taloutta luonnon alasysteeminä toisin kuin "tavanomainen" tai ympäristötaloustiede (Pearse 2002; Røpke 2004). Ekologinen taloustiede tutkii myös valtasuhteiden vaikutusta ympäristöongelmiin ja 
pyrkii liittämään sen, miten taloustiedettä harjoitetaan teoriassa ja käytännössä, osaksi ekosysteemiin kohdistuvien vaikutusten analyysia (Spash ja Ryan 2012).

Vuosisadan puolivälin ympäristöliike nousi siis myös tieteentekijöiden joukossa. Monia edelleen keskeisiä kysymyksiä käsiteltiin klassikoiksi nousseissa teoksissa, kuten taloustieteilijä E.F. Schumacherin teoksessa Pieni on kaunista (Small is Beautiful: A Study of Economics as if People Mattered) vuodelta 1973. Tieteellisesti tarkat ja pitävät huomiot eivät kuitenkaan saaneet merkittävää poliittista jalansijaa ennen talouden globalisoitumista ja ympäristöongelmien "räjähtämistä käsiin". Kun ongelmat viimein saivat osakseen huomiota, alkoi hallintajärjestelmä kompastella paitsi ylikansallisen päätöksenteon lähtökohtaiseen hankaluuteen myös vallitsevien ideologioiden yhteensopimattomuuteen aitojen ratkaisumahdollisuuksien kanssa (esim. Mason 2008; Rosenberg 1994). Vaihtoehtoisia lähestymistapoja vaivasivat myös erimielisyydet tietyistä peruskysymyksistä. Siinä missä ekologinen taloustiede näki sekä talous- että väestönkasvun ongelmana, olivat yhteiskuntaekologit sitä mieltä, että vain talouskasvu on ongelma ympäristön kannalta, kun taas väestönkasvuun liittyvät sosiaaliset ongelmat ovat oikeudenmukaisen tulonjaon kysymys, jota ei ole mahdotonta ratkaista rajallisessakaan maailmassa (Clapp ja Dauvergne 2011; Price 2012).

Kuten edellä kuvasimme, kansainvälisiä ympäristöhallinnan instituutioita ryhdyttiin luomaan näihin samoihin aikoihin, jolloin uusliberalismi alkoi saada jalansijaa taloudellisena pääideologiana. Kasvavien ympäristöongelmien ratkaisu ei siis ole ollut kiinni tiedon tai asiantuntemuksen puutteesta, vaan se on ollut poliittinen kysymys (Newell 2008). Perustavanlaatuisen muutoksen vaatimus (ks. Li 2009) ja sen taustojen ymmärtäminen tieteellisesti on ollut useiden tutkimusalojen kiinnostuksen kohde. Politiikan tekoa sen sijaan ovat ohjanneet valtavirtaa edustavat taloustieteilijät (Ehrlich 1989). Tämän lisäksi ylikansallisten yhtiöiden poliittinen vaikutusvalta on kasvanut mittasuhteisiin, joissa ne voivat vaikuttaa kansainvälisiin instituutioihin - ympäristön näkökulmasta tarkastellen useimmiten rampauttavasti (Levy ja Prakash 2003; Vatn 2007; Wittneben ym. 2012).

Politiikassa on kuitenkin tarjottu runsaasti yllä mainittujen talousteorioiden varassa mallinnettuja vaihtoehtoja vaihdellen sitovan kansainvälisen lainsäädännön vahvistamisesta (Abbott ja Snidal 2000) kansainvälisten instituutioiden uudistamiseen siten, että ei-valtiollisten, ylikansallisten 
toimijoiden vaikutusvaltaa rajoitettaisiin (Newell 2008) aina yksinkertaiseen luonnonvarojen käytölle asetettaviin sitoviin rajoihin (Alcott 2005). Kuten Shiva (1992) toteaa, todellinen kestävä kehitys asettaisi luonnontalouden (nature's economy) etusijalle ja näkisi rahatalouden luonnontalouden loisena. Näiden mallien puitteissa voisi olla mahdollista saavuttaa myös liiketoiminnan ympäristöllinen kestävyys. Mikään näistä vaihtoehdoista ei kuitenkaan vallitsevassa poliittisessa ilmapiirissä ole ottanut tuulta alleen.

\section{Pohdintaa}

Ihminen on muutaman viimeisen vuosikymmenen aikana ehdollistunut ajattelemaan yhteiskunnallisia asioita talouden ehdoilla. Tilanteessa, jossa julkiselta sektorilta katsotaan luonnolliseksi vaatia tuottavuutta, ei liene omituista, että ympäristö - materiaalisia resursseja tarjoava voimavara katsotaan taloudelle alisteiseksi tai ympäristönsuojelun odotetaan olevan kannattavaa liiketoimintaa. Kuten Daly (1990) huomautti käsitteen "kestävä kasvu" sisäisestä ristiriidasta, on vastaava kategorinen virhe Sagoffin (1988) mukaan yrityksessä laittaa ympäristölle hinta ja välinearvo voiton tuottamisen välineenä. Ympäristö on arvo sinänsä ihmisille jo siksi, että sen säilyminen vähintään siedettävässä tilassa on ehto kaikelle elämälle. Ympäristön tilaa voidaan mitata korkeintaan laadullisin kriteerein, eivätkä ympäristö ja raha ole toistensa substituutteja.

Yhä useammat tutkijat eri tieteenaloilta ovat alkaneet vaatia, että maksimaalisen tehokkaan sijasta keskityttäisiin siihen, mikä on ihmisille materiaalisesti riittävää (Clapp ja Dauvergne 2011; Lewin 1995; Princen 2005). Samaan aikaan valtavirran taloustiede, jonka oppeja politiikanteossa useimmiten seurataan, näyttää sivuuttavan kaiken tutkimustiedon siitä, kuinka ympäristöongelmat liittyvät elimellisesti talouskasvuun, sekä toistaa viestiään kasvun välttämättömyydestä ja teknologisen kehityksen mahdollisuuksista. Tieteellisen tiedon perusteella usko teknologian mahdollisuuksiin ja jatkuvaan talouskasvuun on kuitenkin ideologista, ei tosiasiallisiin mahdollisuuksiin tai vaihtoehtoihin perustuvaa. Keskustelua niin ajattelun perusteista kuin konkreettisista toimista ei myöskään helpota ideologiaan vahvasti iskostunut ajatus talouskasvun kyseenalaistajien epärationaalisuudesta, joka elää vahvana erityisesti talouseliitin piirissä. Tämän osoitti 
esimerkiksi pitkän linjan talousvaikuttaja ja Aalto-yliopiston kauppakorkeakoulun taloustieteen Professor of Practice Sixten Korkman Helsingin sanomien marraskuussa 2015 julkaisussa tekstissään leimaten kyseenalaistajat yksioikoisesti "hörhöiksi" - vaatien samalla päätöksentekijöiltä luonnon rajallisuuden myöntämistä (Helsingin Sanomat 19.11.2015).

Onko liiketoimintamalleja mahdollista muuttaa niin, että ympäristö käsitettäisiin arvona sinänsä, ja ymmärrettäisiin, että jatkuvaan talouskasvuun perustuva malli on ympäristöllisesti kestämätön? Vaikka ekologinen taloustiede uskoo ihmisiin muutosvoiman agentteina (Spash ja Ryan 2012), onko muutos mahdollinen niin kauan, kun suurin osa ihmisistä, tiedostamattaan tai ehdollistuneena vallitsevalle hegemonialle, ajattelee uusliberalistisesti (Peck 2010), ja kun keskustelua käydään lähinnä markkinamekanismien implementoinnin laajuudesta ja toimintaohjeiden laatimisesta? Poliittinen ja julkinen keskustelu pyörivät talouden ulkoisvaikutusten ympärillä, vaikka nykyinen talousmalli on ihmisen kehittämä ekosysteemin loinen, joka hitaasti, mutta yhä kiihtyvässä tahdissa on tuhoamassa isäntänsä. Tieteellisiä tai edes aitoja taloudellisia tai oikeudellisia esteitä muutokselle ei ole, joten pullonkaulana on poliittinen tahto olla muuttamatta talouden ensisijaisuuteen nojaavia rakenteita. Kun lainsäädäntö on pitkälti valjastettu palvelemaan suuryritysten ja pääoman tarpeita, on tämä hegemonia vaikea rikkoa.

\section{Lähteet}

Abbott, Kenneth ja Snidal, Duncan. 2000. Hard and soft law in international governance. International organization, 54:3, 421-456.

Alcott, Blake. 2005. Jevons' paradox. Ecological Economics, 54:1, 9-21.

Andersen, Paul ja Sørensen, Evelyne. 2011. The principle of shareholder primacy in company law from a Nordic and European regulatory perspective. Teoksessa Hanne Birkmose, Mette Neville ja Karsten Engsig Sørensen (toim.), The European Financial Market in Transition. Alphen aan den Rijn: Kluwer Law International, 169-198.

Baade, Hans. 1980. The legal effects of codes of conduct for multinational 
enterprises: an introductory survey. Teoksessa Norbert Horn (toim.), Legal problems of codes of conduct for multinational enterprises. Deventer: Kluwer, 407-441.

Banerjee, Subhabrata Bobby. 2008. Corporate Social Responsibility: The Good, the Bad and the Ugly. Critical Sociology, 34:1, 51-79.

Banerjee, Subhabrata Bobby. 2012. A climate for change? Critical reflections on the Durban United Nations climate change conference. Organization Studies, 33:12, 1761-1786.

Banerjee, Subhabrata Bobby. 2014. A critical perspective on corporate social responsibility. Towards a global governance framework. Critical perspectives on international business, 10:1/2, 84-95.

Barkemeyer, Ralf, Holt, Diane, Preuss, Lutz ja Tsang, Stephen. 2014. What happened to the 'development' in sustainable development? Business guidelines two decades after Brundtland. Sustainable Development, 22:1, 15-32.

Blowfield, Michael. 2007. Reasons to be cheerful? What we know about CSR's impact. Third World Quarterly, 28:4, 683-695.

Bernstein, Steven. 2001. The compromise of liberal environmentalism. New York: Columbia University Press.

Bernstein, Steven, Betsill, Michele, Hoffmann, Matthew ja Paterson, Matthew. 2010. A tale of two Copenhagens: carbon markets and climate governance. Millennium - Journal of International Studies, 39:1, 161-173.

Bled, Amadine. 2009. Business to the rescue: private sector actors and global environmental regimes' legitimacy. International Environmental Agreements: Politics, Law and Economics, 9:2, 153-171.

Borck, Jonathan C. ja Coglianese, Cary (2009). Voluntary Environmental Programs: Assessing Their Effectiveness. Annual Review of Environment and Resources 34: 305-324.

Böhm, Steffen, Misoczky, Maria Ceci ja Moog, Sandra. 2012. Greening capitalism? A Marxist critique of carbon markets. Organization Studies, 33:11, 1617-1638. 
Carroll, Archie. 1999. Corporate Social Responsibility. Evolution of a definitional construct. Business and Society, 38:3, 268-295.

Cato, Molly Scott. 2009. Green economics: an introduction to theory, policy and practice. Lontoo: Earthscan.

Clapp, Jennifer ja Dauvergne, Peter. 2011. Paths to a green world: the political economy of the global environment. Lontoo: MIT Press.

Colby, Michael. 1991. Environmental management in development: the evolution of paradigms. Ecological Economics, 3:3, 193-213.

Daly, Herman. 1990. Toward some operational principles of sustainable development. Ecological Economics, 2:1, 1-6.

Daly, Herman. 1993. Sustainable growth: an impossibility theorem. Teoksessa Herman Daly ja Kenneth Townsend (toim.), Valuing the earth: Economics, ecology, ethics. Lontoo: MIT Press, 267-273.

Djelic, Marie-Laure ja Etchanchu, Helen. 2015. Contextualizing corporate political responsibilities: Neoliberal CSR in historical perspective. Journal of Business Ethics. Online before print. http://link.springer.com/article/10.1007 \%2Fs10551-015-2879-7\# [Luettu 29.12.2015]

Dyllick, Thomas and Muff, Katrin. 2015. Clarifying the meaning of sustainable business: Introducing a typology from business-as-usual to true business sustainability. Organization and Environment. Online before print. http://oae. sagepub.com/content/early/2015/02/12/1086026615575176.abstract [Luettu 29.12.2015]

Ehrlich, Paul. 1989. The limits to substitution: meta-resource depletion and a new economic-ecological paradigm. Ecological Economics, 1:1, 9-16.

Frankental, Peter. 2001. Corporate social responsibility - a PR invention? Corporate Communications: An International Journal, 6:1, 18-23.

Goodland, Robert ja Ledec, George. 1987. Neoclassical economics and principles of sustainable development. Ecological Modelling, 38:1, 19-46.

Grembi, Veronica. 2007. The imperialistic aim of economics: at the origin of the economic analysis of law. History of Economic Ideas, 15:3, 139-164. 
Hallituksen esitys Eduskunnalle uudeksi osakeyhtiölaiksi (HE 109/2005).

Hansmann, Henry ja Kraakman, Reinier. 2000. The end of history for corporate law. Georgetown Law Journal, 89, 439-468.

Helsingin Sanomat. 19.11.2015. Sixten Korkman: Sekä jäärät että hörhöt ovat väärässä: talouskasvu ja ympäristö eivät ole toistensa vihollisia. Saatavana: http://www.hs.fi/talous/a1447913346310 [Luettu 29.12.2015]

Hertig, Gerard. 2000. Western Europe's corporate governance dilemma. Teoksessa Theodor Baums, Klaus Hopt ja Norber Horn (toim.), Corporations, capital markets and business in the law (liber amicorum Richard M. Buxbaum). Lontoo: Kluwer Law International, 265-282.

Horn, Laura. 2012. Corporate Governance in crisis? The politics of EU corporate governance regulation. European Law Journal, 18:1, 83-107.

Jackson, Tim 2011. Prosperity without growth: Economics for a finite planet. Lontoo: Routledge.

Johansson, Johana. 2012. Challenges to the legitimacy of private forest governance-the development of forest certification in Sweden. Environmental Policy and Governance, 22:6, 424-436.

Kates, Robert, Turner II, B.L Richards, John ja Clark, William. 1993. The great transformation. Teoksessa B.L Turner II, William Clark, Robert Kates, John Richards, Jessica Mathews ja William Meyer (toim.), The Earth as transformed by human action: global and regional changes in the biosphere over the past 300 years. Cambridge: Cambridge University Press, 1-17.

Kolk, Ans, Levy, David, ja Pinkse, Jonatan. 2008. Corporate responses in an emerging climate regime: the institutionalization and commensuration of carbon disclosure. European Accounting Review, 17:4, 719-745.

Kulovesi, Kati. 2014. Real or imagined controversies? A climate law perspective on the growing links between the international trade and climate change regimes. Trade, Law and Development, 6:1, 55-92.

Lélé, Sharachchandra. 1991. Sustainable development: A critical review. World Development, 19:6, 607-621. 
Levy, David. 2011. Private sector governance for a sustainable economy: a strategic approach. Review of Policy Research, 28:5, 487-493.

Levy, David ja Prakash, Aseem. 2003. Bargains old and new: Multinational corporations in global governance. Business and Politics, 5:2, 131-150.

Li, Minqi. 2009. Capitalism, climate change and the transition to sustainability: alternative scenarios for the US, China and the World. Development and Change, 40:6, 1039-1061.

Lewin, Jeff. 1995. Toward a new ecological law and economics. Teoksessa Robin Malloy ja Christopher Braun (toim.), Law and economics: new and critical perspectives. New York: Peter Lang, 249-294.

Mason, Michael. 2008. The governance of transnational environmental harm: addressing new modes of accountability/responsibility. Global Environmental Politics, 8:3:, 8-24.

Midttun, Atle, Gautesen, Kristian ja Gjølberg, Maria. 2006. The political economy of CSR in Western Europe. Corporate Governance, 6:4, 369-385.

Mont Pelerin Society. 1947. Statement of aims. 8.4.1947. https://www. montpelerin.org/montpelerin/mpsGoals.html [Luettu 29.12.2015]

Montiel, Ivan ja Delgado-Ceballos, Javier. 2014. Defining and measuring corporate sustainability. Are we there yet? Organization and Environment, 27:2, 113-139.

Mitchell, Catherine. 2008. The political economy of sustainable energy. Basingstoke: Palgrave Macmillan.

Moon, Jeremy, Crane, Andrew ja Matten, Dirk. 2005. Can corporations be citizens? Corporate citizenship as a metaphor for business participation in society. Business Ethics Quarterly, 15:3, 429-453.

Newell, Peter. 2008. The political economy of global environmental governance. Review of International Studies, 34:3, 507-529.

Paavola, Jouni, Gouldson, Andrew ja Kluvánková-Oravská, Tatiana. 2009. Interplay of actors, scales, frameworks and regimes in the governance of biodiversity. Environmental Policy and Governance, 19:3, 148-158. 
Pattberg, Philipp ja Widerberg, Oscar. 2015. Theorising global environmental governance: key findings and future questions. Millennium - Journal of International Studies, 43:2, 684-705.

Pearce, David. 2002. An intellectual history of environmental economics. Annual Review of Energy and the Environment, 27:1, 57-81.

Peck, Jamie. 2010. Constructions of neoliberal reason. Oxford: Oxford University Press.

Price, Andy. 2012. Recovering Bookchin. Social ecology and the crises of our time. Porsgrunn: New Compass Press.

Princen, Thomas. 2005. The logic of sufficiency. Cambridge, MA: MIT Press.

Rosenberg, Robin. 1994. Trade and the environment: economic development versus sustainable development. Journal of Inter-American Studies and World Affairs, 36:3, 129-156.

Røpke, Inge. 2004. The early history of modern ecological economics. Ecological Economics, 50:3, 293-314.

Salzmann, Oliver, Ionescu-Somers, Aileen ja Steger, Ulrich. 2005. The business case for corporate sustainability: literature review and research options. European Management Journal, 23:1, 27-36.

Sandoval, Marisol. 2015. From CSR to RSC. A contribution to the critique of the political economy of corporate social responsibility. Review of Radical Political Economics, 47:4, 608-624.

Scherer, Andreas ja Palazzo, Guido. 2008. Globalization and corporate social responsibility. Teoksessa Andrew Crane, Abigail McWilliams, Dirk Matten, Jeremy Moon ja Donald Siegel (toim.), The Oxford handbook of corporate social responsibility. Oxford: Oxford University Press, 413-431.

Scherer, Andreas ja Palazzo, Guido. 2011. The new political role of business in a globalized world: A review of a new perspective on CSR and its implications for the firm, governance, and democracy. Journal of Management Studies, 48:4, 899-931.

Shiva, Vandana. 1992. Recovering the real meaning of sustainability. Teoksesa 
David Cooper ja Joy Palmer (toim.), The Environment in Question: Ethics and Global Issues. New York: Routledge, 187-193.

Spash, Clive ja Ryan, Anthony. 2012. Economic schools of thought on the environment: investigating unity and division. Cambridge Journal of Economics, 36:5, 1091-1121.

Vatn, Arild. 2007. Institutions and the environment. Cheltenham: Edward Elgar.

Vogel, David. 2007. The market for virtue: the potential and limits of corporate social responsibility. Washington DC: Brookings Institution Press.

Wittneben, Bettina, Okereke, Chukwumerije, Banerjee, Subhabrata Bobby ja Levy, David. 2012. Climate change and the emergence of new organizational landscapes. Organization Studies, 33:11, 1431-1450.

WCED [World Commission on environment and development]. 1987. Our common future. Report of the World Commission on environment and development. Oxford: Oxford University Press. 